Pacific Journal of Mathematic 


\section{A REFINEMENT OF SELBERG'S ASYMPTOTIC EQUATION}

VeIKKo NeVANLINNA

The elementary proofs of the prime number theorem are essentially based on asymptotic equations of the form

$$
f(x) \log x+\int_{1}^{x} f\left(\frac{x}{t}\right) d \psi(t)=O(x),
$$

where $f(x)$ is some function concerning the primes, $\phi(x)$ is Tchebychev's function and the limits in the integral-as throughout in this paper-are taken from 1 - to $x+$. This paper gives an elementary method for refining the right hand side of $(\mathbf{A})$.

This method is based on the lemma of Tatuzawa and Iseki [2], and, assuming the prime number theorem, on an estimation of remainder integral which is more accurate than earlier ones.

Writing

$$
\psi(x)=\sum_{n \leqq x} \Lambda(n)=\sum_{p \nu \geqq x} \log p, \quad R(x)=\psi(x)-x
$$

we have the two equivalent forms of Selberg's asymptotic equation

$$
\begin{aligned}
& R(x) \log x+\int_{1}^{x} R\left(\frac{x}{t}\right) d \psi(t)=O(x), \\
& \psi(x) \log x+\int_{1}^{x} \psi\left(\frac{x}{t}\right) d \psi(t)=2 x \log x+O(x),
\end{aligned}
$$

each of which is known to imply the prime number theorem: $\psi(x)=$ $x+o(x)$. In this paper we give refinements of (1) and (2), showing that

$$
\begin{aligned}
& R(x) \log x+\int_{1}^{x} R\left(\frac{x}{t}\right) d \psi(t)=-(\gamma+1) x+o(x), \\
& \psi(x) \log x+\int_{1}^{x} \psi\left(\frac{x}{t}\right) d \psi(t)=2 x \log x-(2 \gamma+1) x+o(x),
\end{aligned}
$$

where $\gamma$ denotes Euler's constant. The prime number theorem, however, has then to be assumed. In addition, we give some similar results.

2. Using the idea of Tatuzawa and Iseki [2] we start from the following 
Lemma. Let $f(x)$ be defined for all $x \geqq 0$ and let

$$
g(x)=\log x \sum_{n \leqq x} f\left(\frac{x}{n}\right)=\log x \int_{1}^{x} f\left(\frac{x}{t}\right) d[t] .
$$

Then

$$
f(x) \log x+\int_{1}^{x} f\left(\frac{x}{t}\right) d \psi(t)=\int_{1}^{x} g\left(\frac{x}{t}\right) d M(t),
$$

where

$$
M(x)=\sum_{n \leqq x} \mu(n) .
$$

The Lemma follows immediately by substituting the expression (3) for $g$ in the right hand side of (4) and noting that

$$
\Lambda(n)=\sum_{d \backslash n} \mu(d) \log \frac{n}{d}=-\sum_{d / n} \mu(d) \log d .
$$

Inserting $f(x)=R(x)$ in (4), we obtain the left hand side of (1'). On the other hand,

$$
\begin{aligned}
\sum_{n \leqq x} \psi\left(\frac{x}{n}\right)=\sum_{n \leqq x} \log n & =x \log x-x+O(\log x) \\
= & x \sum_{n \leqq x} \frac{1}{n}-(\gamma+1) x+O(\log x),
\end{aligned}
$$

and writing $x=[x]+O(1)$, we obtain

$$
g(x)=\log x\left(\sum_{n \leqq x} \psi\left(\frac{x}{n}\right)-\sum_{n \leqq x} \frac{x}{n}\right)=\log x(-(\gamma+1)[x]+u(x)),
$$

where $u(x)=O(\log x)$. Thus we have

$$
\int_{1}^{x} g\left(\frac{x}{t}\right) d M(t)=-(\gamma+1) \int_{1}^{x}\left[\frac{x}{t}\right] \log \frac{x}{t} d M(t)+\int_{1}^{x} u\left(\frac{x}{t}\right) \log \frac{x}{t} d M(t) .
$$

From the lemma with $f(x) \equiv 1$ we see that the first expression on the right can be written as

$$
-(\gamma+1)(\log x+\psi(x))=-(\gamma+1) x+o(x),
$$

assuming the prime number in the form $\psi(x)=x+o(x)$. This yield $R(x) \log x+\int_{1}^{x} R\left(\frac{x}{t}\right) d \psi(t)=-(\gamma+1) x+o(x)+\int_{1}^{x} u\left(\frac{x}{t}\right) \log \frac{x}{t} d M(t)$, which proves $\left(1^{\prime}\right)$, as soon as we can show that the last expression is $o(x)$. We choose $0<\delta<1$ and write 


$$
I=\int_{1}^{x} u\left(\frac{x}{t}\right) \log \frac{x}{t} d M(t)=\int_{1}^{\delta x}+\int_{\delta x}^{x}=I_{1}+I_{2} .
$$

The integral $I_{1}$ can, by virtue of $u(x)=O(\log x)$, be estimated as follows:

$$
I_{1}=O\left(\int_{1}^{\delta x} \log ^{2} \frac{x}{t} d[t]\right)=O\left(\int_{0}^{\delta x} \log ^{2} \frac{x}{t} d t\right)=\eta(\delta) x,
$$

where $\eta(\delta)$ vanishes with $\delta$. In order to estimate $I_{2}$ we choose an arbitrary $\varepsilon>0$ and $x^{\prime}>0$ such that $|M(x)|<\varepsilon x$, if $\delta x>x^{\prime}$, which can be done by the prime number theorem. Then, integrating by parts, we obtain

$$
\begin{aligned}
\left|I_{2}\right| & \leqq\left|\log \frac{1}{\delta} u\left(\frac{1}{\delta}\right) M(\delta x)\right|+\left|\int_{\delta x}^{x} M(t) d\left(\log \frac{x}{t} u\left(\frac{x}{t}\right)\right)\right| \\
& \leqq \log \frac{1}{\delta}\left|u\left(\frac{1}{\delta}\right)\right| \delta \varepsilon x+\left[\int_{1}^{1 / \delta} \frac{|d(\log t u(t))|}{t}\right] \varepsilon x=K_{\delta} \varepsilon x,
\end{aligned}
$$

where $K_{\delta}$ is a constant depending only on $\delta$. Thus we can choose the number $\delta$ small enough to make the expression $\left|I_{1}\right| / x$ arbitrary small and then for fixed $\delta$ choose the value of $x\left(>x^{\prime}\right)$ so that the same holds for $I_{2}$. Thus we have $I=I_{1}+I_{2}=o(x)$, and $\left(1^{\prime}\right)$ is proved. $\left(2^{\prime}\right)$ then follows immediately by inserting $R(x)=\psi(x)-x$ and observing the equation

$$
\int_{1}^{x} \frac{d \psi(t)}{t}=\log x-\gamma+o(1)
$$

which also follows from the prime number theorem.

3. The method used above can be applied to several similar problems. Taking the prime number theorem for granted and using (3) and (4) with $f(x)$ equal to

$$
M(x)=\sum_{n \leqq x} \mu(n)
$$

or

$$
x B(x)=x \sum_{n \leqq x} \frac{\mu(n)}{n},
$$

we obtain (see [1] p. 36)

$$
\begin{aligned}
& M(x) \log x+\int_{1}^{x} M\left(\frac{x}{t}\right) d \psi(t)=o(x) \\
& B(x) \log x+\int_{1}^{x} B\left(\frac{x}{t}\right) \frac{d \psi(t)}{t}=1+o(1) .
\end{aligned}
$$


Futhermore, writing

$$
\varepsilon(x)=\int_{1}^{x} \frac{d \psi(t)}{t}-\log x+\gamma=h(x)-\log x+\gamma,
$$

and applying the same method to the function $x \varepsilon(x)$, we can show that (see [1] pp. 22-23)

$$
\varepsilon(x) \log x+\int_{1}^{x} \varepsilon\left(\frac{x}{t}\right) d h(t)=\left(\kappa+\gamma^{2}\right)+o(1),
$$

or

$$
\int_{1}^{x} h\left(\frac{x}{t}\right) d h(t)+\int_{1}^{x} \log t d h(t)=\log ^{2} x-2 \gamma \log x+\kappa+2 \gamma^{2}+o(1),
$$

where

$$
\kappa=\lim _{x \rightarrow \infty}\left(2 \sum_{n \leqq x} \frac{\log n}{n}-\log ^{2} x\right) .
$$

Wirsing ([3] p. 8) gives by stronger assumption and assertion a similar result for the function

$$
r(x)=\sum_{n \leqq x}\left(\frac{1}{n}-\frac{\Lambda(n)}{n}\right)-2 \gamma .
$$

Corresponding equations concerning the prime number theorem for arithmetic progressions can also be deduced.

In concluding, I wish to thank Professor Kenneth Rogers for helpful conversations and other assistance with this paper.

\section{REFERENCES}

1. V. Nevanlinna, Über die elementaren Beweise der Primzahlsätze and deren äquivalente Fassungen, Ann. Acad. Sci. Fenn. (AI) 343 (1964).

2. T. Tatuzawa and K. Iseki, On Selberg's elementary proof to the prime-number theorem, Proc. Japan Acad. 27 (1951), 340-342.

3. E. Wirsing, Elementare Beweise des Primzahlsatzes mit Restglied II, J. Reine Angew. Math. 214/215 (1964), 1-18.

Received May 26, 1966.

UNIVERSITY OF HAWAII AND

UNIVERSITY OF JYVÄSKYLÄ, FINLAND 


\section{PACIFIC JOURNAL OF MATHEMATICS}

\section{EDITORS}

\section{H. SAMELSON}

Stanford University

Stanford, California

\author{
J. P. JANS \\ University of Washington \\ Seattle, Washington 98105
}

\section{J. DuGUNDJI}

University of Southern California

Los Angeles, California 90007

RichaRd ARENS

University of California

Los Angeles, California 90024

\section{ASSOCIATE EDITORS}

E. F. BECKENBACH
B. H. NeUManN

F. WOLF

K. YOSIDA

\section{SUPPORTING INSTITUTIONS}

UNIVERSITY OF BRITISH COLUMBIA

CALIFORNIA INSTITUTE OF TECHNOLOGY

UNIVERSITY OF CALIFORNIA

MONTANA STATE UNIVERSITY

UNIVERSITY OF NEVADA

NEW MEXICO STATE UNIVERSITY

OREGON STATE UNIVERSITY

UNIVERSITY OF OREGON

OSAKA UNIVERSITY

UNIVERSITY OF SOUTHERN CALIFORNIA
STANFORD UNIVERSITY

UNIVERSITY OF TOKYO

UNIVERSITY OF UTAH

WASHINGTON STATE UNIVERSITY

UNIVERSITY OF WASHINGTON

AMERICAN MATHEMATICAL SOCIETY

CHEVRON RESEARCH CORPORATION

TRW SYSTEMS

NAVAL ORDNANCE TEST STATION

Mathematical papers intended for publication in the Pacific Journal of Mathematics should be typewritten (double spaced). The first paragraph or two must be capable of being used separately as a synopsis of the entire paper. It should not contain references to the bibliography. Manuscripts may be sent to any one of the four editors. All other communications to the editors should be addressed to the managing editor, Richard Arens at the University of California, Los Angeles, California 90024.

50 reprints per author of each article are furnished free of charge; additional copies may be obtained at cost in multiples of 50 .

The Pacific Journal of Mathematics is published monthly. Effective with Volume 16 the price per volume ( 3 numbers) is $\$ 8.00$; single issues, $\$ 3.00$. Special price for current issues to individual faculty members of supporting institutions and to individual members of the American Mathematical Society: $\$ 4.00$ per volume; single issues $\$ 1.50$. Back numbers are available.

Subscriptions, orders for back numbers, and changes of address should be sent to Pacific Journal of Mathematics, 103 Highland Boulevard, Berkeley 8, California.

Printed at Kokusai Bunken Insatsusha (International Academic Printing Co., Ltd.), No. 6, 2-chome, Fujimi-cho, Chiyoda-ku, Tokyo, Japan.

PUBLISHED BY PACIFIC JOURNAL OF MATHEMATICS, A NON-PROFIT CORPORATION

The Supporting Institutions listed above contribute to the cost of publication of this Journal, but they are not owners or publishers and have no responsibility for its content or policies. 


\section{Pacific Journal of Mathematics}

\section{Vol. 21, No. $3 \quad$ BadMonth, 1967}

Richard Allen Askey, A transplantation theorem for Jacobi coefficients . . . 393

Raymond Balbes, Projective and injective distributive lattices .......... 405

Raymond Balbes and Alfred Horn, Order sums of distributive lattices . . . . 421

Donald Charles Benson, Nonconstant locally recurrent functions ........ 437

Allen Richard Bernstein, Invariant subspaces of polynomially compact operators on Banach space ............................... 445

Robert F. Brown, Fixed points and fibre ................... 465

David Geoffrey Cantor, On the Stone-Weierstrass approximation theorem for valued fields ................................ 473

James Walton England, Stability in topological dynamics .............. 479

Alessandro Figà-Talamanca and Daniel Rider, A theorem on random

Fourier series on noncommutative groups.................. 487

Sav Roman Harasymiv, A note of dilations in $L^{p} \ldots \ldots \ldots \ldots \ldots \ldots . \ldots 493$

J. G. Kalbfleisch, A uniqueness theorem for edge-chromatic graphs ....... 503

Richard Paul Kelisky and Theodore Joseph Rivlin, Iterates of Bernstein polynomials .................................... 511

D. G. Larman, On the union of two starshaped sets ............... 521

Henry B. Mann, Josephine Mitchell and Lowell Schoenfeld, Properties of differential forms in $n$ real variables ...................... 525

John W. Moon and Leo Moser, Generating oriented graphs by means of team comparisons .

Veikko Nevanlinna, A refinement of Selberg's asymptotic equation ...

Ulrich Oberst, Relative satellites and derived functors of functors with additive domain ..............................

John Vincent Ryff, On Muirhead's theorem...............

Carroll O. Wilde and Klaus G. Witz, Invariant means and the Stone-Čech compactification 